【総】説】

スルフォラファン含有食品, ブロッコリースプラウト摂取 による H.pylori 胃炎軽減作用 亡胃癌予防の可能性

Daily Intake of SulforaphaneRich Broccoli Sprouts Suppresses $H$. pylori Colonization and Attenuates H. pylori-induced Gastritis via Upregulation of Nrf2-dependent Antixodaint Enzymes

谷中昭典 ${ }^{1, *}$, 田内雅史 ${ }^{1}$, 山本雅之 ${ }^{2}$, 兵頭一之介 1

Akinori YANAKA ${ }^{1, *}$, Masafumi TAUCHI ${ }^{1}$, Masayuki YAMAMOTO², Ichinosuke HYODO ${ }^{1}$

1 筑波大学大学院人間総合科学研究科 病態制御医学専攻, 消化器内科

2 東北大学大学院医学系研究科医化学分野
【要 旨】

ブロッコリーの芽に含まれるスルフォラファン (Sfn) は, 酸化ストレス応答転写因子 nrf2 を活性化すること により, 細胞内の抗酸化酵素群を誘導し, 酸化ストレ スによる細胞障害を防止し, in vitro において抗 $H$. pylori $(\mathrm{Hp})$ 作用を発揮する.我々は, $\mathrm{Hp}$ 感染マウス, お よびヒト Hp 感染者において, Sfn 含有食品であるブ ロッコリースプラウト (BS)の摂取により Hp 胃炎を予 防しうるか否かについて検討した. その結果, BS 投 与によりマウス, ヒト両者において, $\mathrm{Hp}$ 菌数は減少 し, 胃炎は軽減した. 以上より, Sfn 含有食品である BS の摂取により, Hp 胃炎の軽減効果が確認され, Sfn による胃癌予防効果が示唆された.

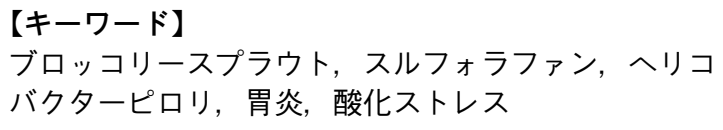

はじめに

近年の研究により胃癌の発症には H. pylori 感染が深く 関与することが次第に明らかになりつつある ${ }^{1,2)}$. 健康な 胃粘膜を有するとトが H. pylori に感染すると, 胃粘膜に は炎症が惹起され，徐々に胃粘膜萎縮が進行し，最終的 に胃癌の発症につながる ${ }^{3)}$. このことから, H. pylori 感染 により惹起される胃炎は胃癌発症の母地と位置づけられ ている. しかしながら，H. pylori 感染者の中で生涯を通 じて胃癌になる人は約 $5 \sim 10 \%$ 程度にすぎない。 また， 近年行わ秃ている臨床介入研究の結果を見る限り，H. pylori 除菌による胃癌予防効果には限界がある 4 ,. 。 これ らの報告から, 胃癌の発症には, H. pylori 以外の環境因 子も重要であることが想定され，その中でも，とりわけ 食餌性因子が深く関与する可能性を指摘する疫学的報告 が多い6-8). 胃癌発症を促進する食餌性因子として，これ までの報告によれば，食塩の摂取量と胃癌の罹患率に強 い相関が認められている9)。これに対して，野菜，果物 類には胃がんの発症を抑制する食品が多いことが指摘さ れているが8)，その詳細な作用機序は明らかではない，今 後，食品による胃がん予防対策を考光る上で，これらの 食品の発がん抑制作用機序を解明し，その臨床的有用性 を検証していくことは非常に重要である.

発がん予防食品の研究分野に执いて，ブロッコリーの 新芽（ブロッコリースプラウト）に豊富に含まれるスル フォラファンといら物質が最近注目されている10,11) (図 1).スルフォラファンは, 酸化ストレス応答遺伝子であ

受理日：2006 年 12 月 30 日

* 干305-8575 茨城県つくば市天王台 1-1-1 筑波大学大学院人間総合科学研究科（消化器内科） Tel: 029-853-3210 Fax: 029-853-3218 E-mail: ynk-aki@md.tsukuba.ac.jp 
スルフォラファン ブロッコリーの新芽
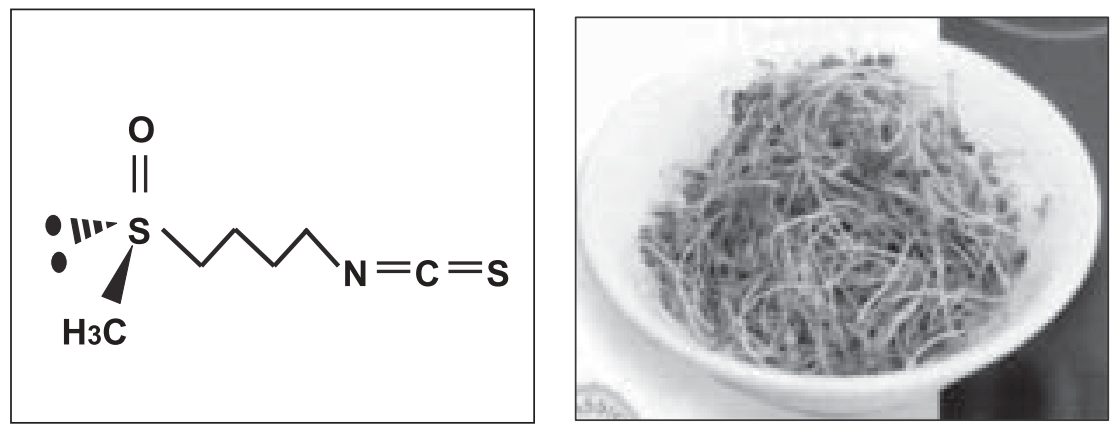

図 1 スルフォラファンとブロッコリースプラウト

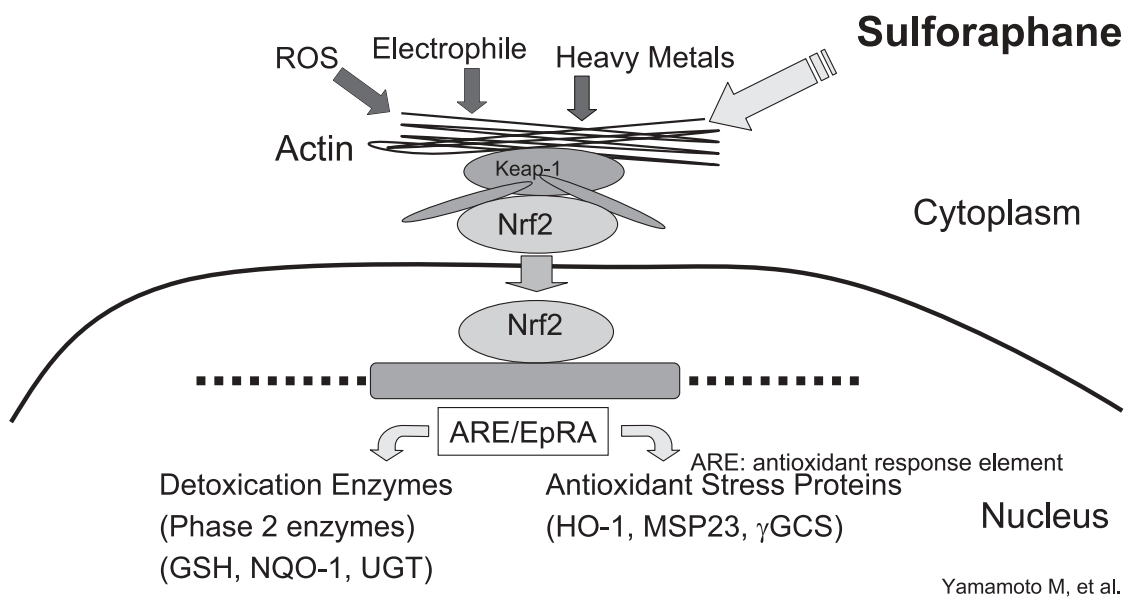

図 2 Nrf2 を介するスルフォラファンの抗酸化酵素刺激作用

る Nrf2 (NF-E2 p45-related factor-2) と呼ばれる転写因子を 介して，抗酸化酵素群を誘導することにより，酸化スト レスによる DNA 障害から細胞を防御する ${ }^{12}$ ) (図 2)。さ らにスルフォラファンは in vitro において抗 H. pylori 作 用を有する13).

これらの背景に基づき，我々は H. pylori 感染マウスや H. pylori 感染者に対して, スルフォラファン含有食品で あるブロッコリースプラウトを経口摂取させることによ り H.pyloriにより惹起される胃炎を軽減しらるか否かを 検討した.

高塩分食負荷 H.pylori 感染マウス胃粘膜におけるスル

$$
\text { フォラファンの胃炎軽減作用 }
$$

6 週令の野生型 C57/BL6 マウスにH. pylori（ヒト胃炎 患者から分離した標準株 Sydney Strain-1: SS-1）を経口感 染させると，ヒト（特に欧米人）の胃炎と類似した前庭 部優位の慢性胃炎が惹起される ${ }^{14)}$. さらに, この H. pylori
感染マウスに高塩分食を長期間投与すると，胃粘膜の炎 症は前庭部から胃体部へと拡大し，胃体部優位型の胃炎 に変化し, 胃体部粘膜の萎縮を進行させる ${ }^{15,16)}$. 高塩分 食により惹起される胃体部粘膜の萎縮性変化は, 特に日 本人の H. pylori 感染者において頻繁にみられ, 胃癌発症 のリスクとなることが指摘されている ${ }^{1,17)}$. すなわち，H pylori 感染マウスに対する高塩分食の長期投与は, マウ スの胃粘膜を胃癌になりにくい欧米人型から胃癌になり やすい日本人型に変化させる. 我々は, この H. pylori 感 染十高塩分食負荷マウスモデルを用いて，スルフォラ ファンの胃炎軽減効果を以下の方法で検証した.

\section{1. 動物実験モデル}

既報 ${ }^{14)}$ の如く, 6 週令の野生型, および Nrf2 遺伝子欠 損型 (Nrf-2-/-) マウス ${ }^{18)}$ （いずれも雌, C57/BL6）に $H$. pylori (Sydney Strain-1; SS1) を経口感染させ，慢性胃炎を 作成した。 


\section{2. 実験プロトコール}

上記の H. pylori 感染マウスを, 通常食 $(0.25 \% \mathrm{NaCl})$ 投 与群と高塩分食 $(7.5 \% \mathrm{NaCl})$ 投与群に分け,さらに, 各々 の群を，スルフォラファンを含むブロッコリースプラウ 卜（以下 BS）投与群と非投与群に分け，3ヶ月間飼育し た．BSの投与法は，スルフォラファンを豊富に含む発芽 3 日目の BS（村上農園，ブロッコリースーパースプラウ ト®；スルフォラファン含有量 $258 \mathrm{mg} / 100 \mathrm{~g}$ )をホモジェ ナイズし，スルフォラファンの一日摂取量が $4.5 \mathrm{mg} / \mathrm{kg} /$ day となるよらに調整した水溶液を自由飲水にて投与し た. 投与開始後，1 个月毎にマウスを屠殺，胃粘膜を取 り出し, 以下の項目について検討した.

\section{3. 検討項目}

a) 胃炎・胃粘膜萎縮の評価

Updated Sydney System を用いて胃炎 (慢性炎症), 及 び胃粘膜萎縮の程度を点数化して評価した.

b）胃粘膜 8-OHdG の定量

胃粘膜細胞における DNA 傷害の程度を評価するため に胃粘膜内 8-OHdG 量を ELISA 法にて測定・評価した.

c）胃粘膜抗酸化酵素活性の定量

胃粘膜中に打ける第 2 相解毒酵素である Glutathione-S-

Transferase (GST) 活性を ELISA 法にて測定した.

d）胃粘膜 H. pylori 菌量の評価

胃粘膜ホモジェネートを培養して H. pylori 菌量を定量 した.

\section{成 績}

1. 野生型マウスに扒いて, 高塩分食投与による $H . p y-$ lori 感染群に打忷る胃体部粘膜の炎症の悪化, 胃体 部に扮ける粘膜萎縮の進展, 胃粘膜内 8-OHdG 量の

$$
\text { nrf2 +/+ }
$$
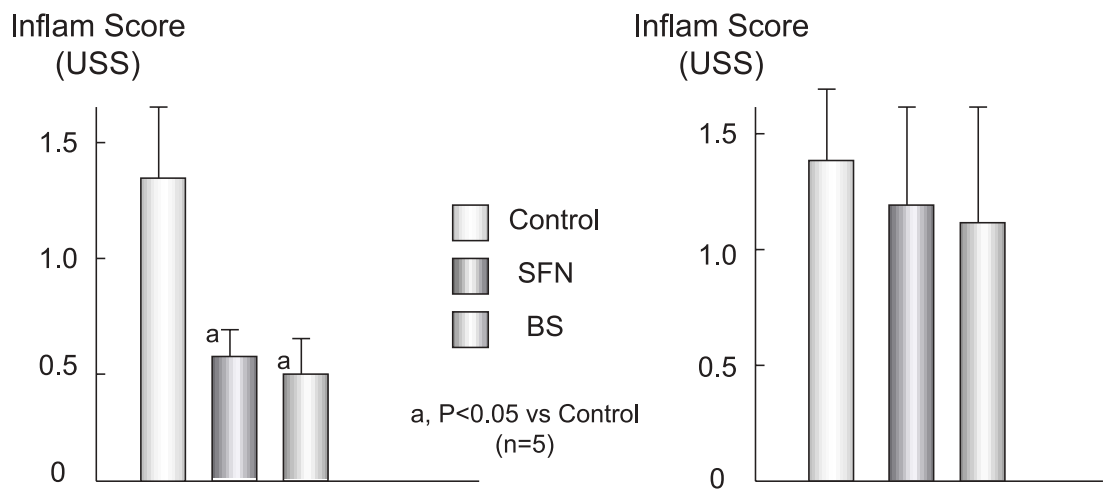

图 4 BS投与による H. pylori 胃炎悪化軽減効果（シドニーシステムによる組織像解析結果）
増大が認められた. 野生型マウスでは, BS 投与によ り高塩分食投与による胃炎悪化に対する防御効果 （図 3，4）, 胃粘膜 GST 活性の増大（図 5）が認めら れた。これに対して，Nrf2 遺伝子欠損マウスでは， ブロッコリースプラウト投与によるこれらの効果は 認められなかった（図4）。

2. 野生型マウスでは，高塩分食投与時に打いて BS 投 与により, H. pylori 菌数の有意な減少が認められた が，nrf2 遺伝子欠損マウスでは H. pylori 菌数に対す る効果は認められなかった。

以上の結果より，スルフォラファンは，nrf2 たして 胃粘膜の酸化ストレス応答能を活性化させ，胃粘膜の免 疫能を強化することにより，H. pylori の菌量を減少させ 胃炎を軽快させるものと考光られた。

ヒトにおけるスルフォラファンの H. pylori 胃炎の軽減 効果

以上の動物実験より, $4.5 \mathrm{mg} / \mathrm{kg} / \mathrm{day}$ のスルフォラファ

- BS

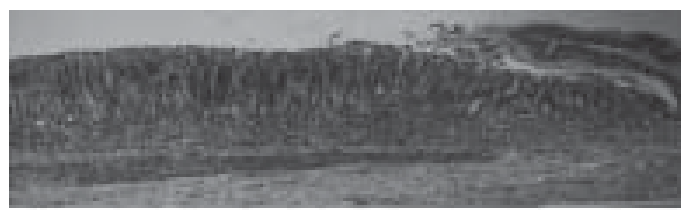

+ BS

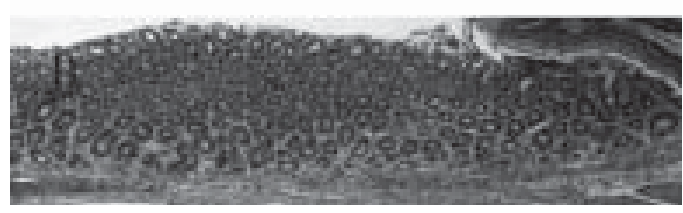

図 3 BS 投与は高塩分食投与による H. pylori 胃炎悪化を防止 する (組織像)

nrf2 -/-

flam Score

(USS) 


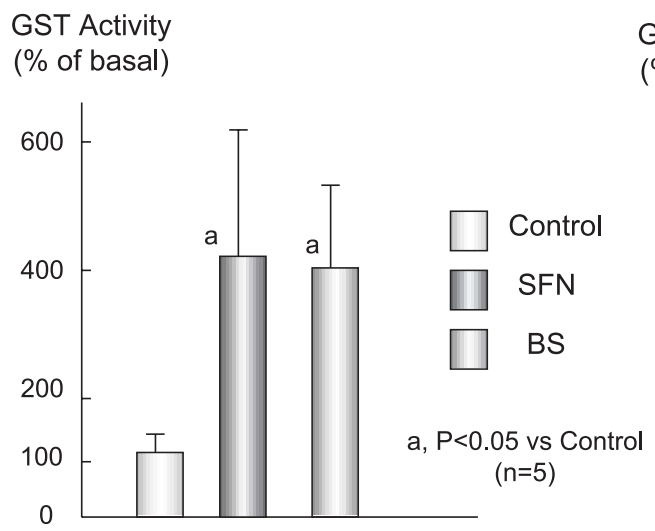

GST Activity

(\% of basal)

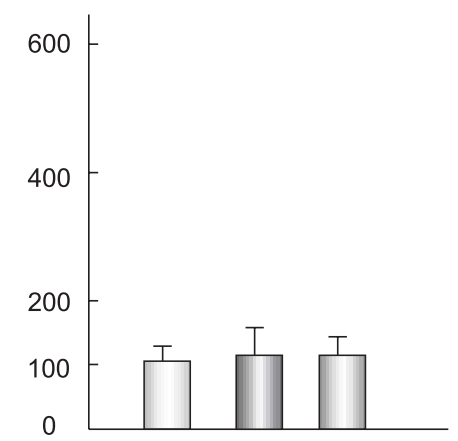

図 5 BS 投与によるマウス胃粘膜 GST 活性増大作用

ン投与がマウスの H. pylori 胃炎を改善させることが明ら かになった. このスルフォラファン量はヒトに換算する と, 体重 $57 \mathrm{~kg}$ の人間が 1 日あたり $100 \mathrm{~g}$ （=2 パック） の BS を撕食することによって摂取可能な量であること から, 我々は, ヒトに打いてもマウスと同様にBSの経口 摂取により, H. plyori 胃炎が改善される可能性を想定し, ヒト (H. pylori 感染者) を対象に BS 投与を行ら臨床介 入試験を計画した.

\section{方 法}

\section{1. 参加対象者の選定}

文書にて本研究への参加について同意が得られたボラ ンティア140 名に対して尿中 H. pylori 抗体検査を実施し
た結果 65 名が H. plyori 陽性であった。. 以上 65 名のうち 60 名の患者に対して病歴を聴取し内視鏡検査を実施し たところ，抗潰瘍薬，NSAIDs の常用歴がなく，かつ内 視鏡的に H. pylori 感染によると思われる胃炎以外の病変 を認めない 50 名を本研究への参加対象者とした.

\section{2. スプラウトによる介入試験の方法}

二重盲検法で介入試験を実施するに当たり, 我々は本 研究に拈いてプラセーボとして用いるべき適当な食品を 模索した．その結果，スルフォラファンを全く含まない 点以外には含有栄養成分, 形状, 風味等が BS と極めて 類似しているアルファルファスプラウト（以下 AS）を プラセーボとして用いることにした. 前述した 50 名の対 象者を BS 群 25 名, AS 群 25 名に無作為に分け, BS 群

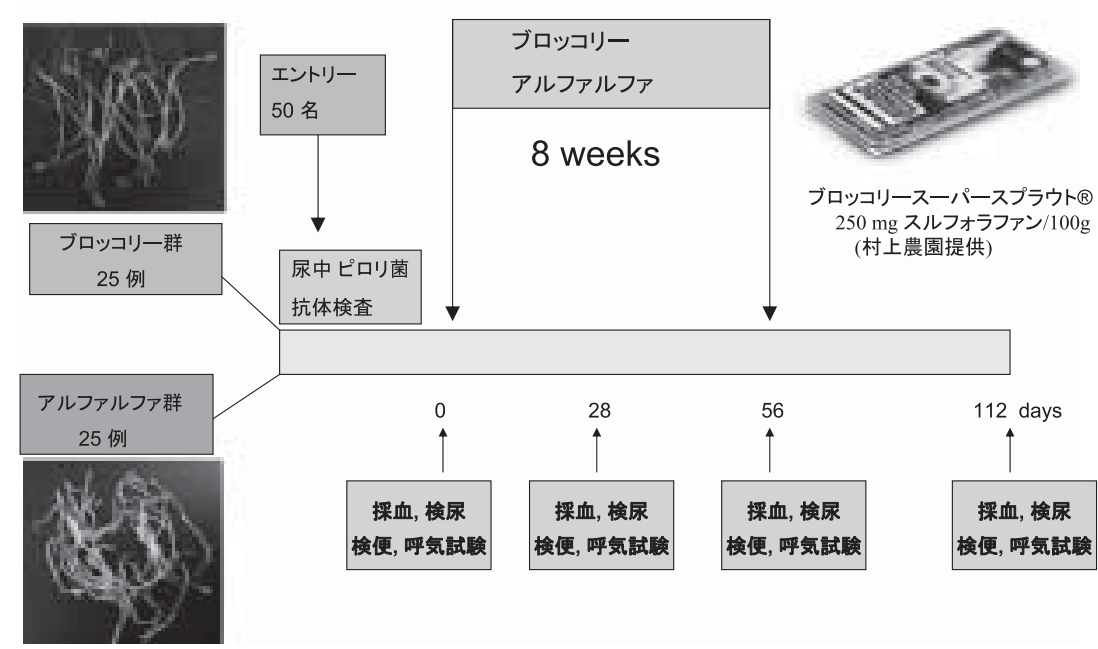

図 6 ヒト H. pylori 胃炎患者に抢ける BS 投与介入試験プロトコール 
には発芽 3 日目の BS（村上農園, ブロッコリースーパー スプラウト®; スルフォラファン含有量 $250 \mathrm{mg} / 100 \mathrm{~g}$ )を, AS 群には AS（スルフォラファン含有量ゼロ）を8週間 毎日 $70 \mathrm{~g} /$ 日ずつ摂食してもらい，摂食開始前，開始 4週 後, 8 週後, 及び拱食終了 8 週後に, 採血, 検尿, 検便, および呼気を採取し，以下の項目について検討した（図 $6)$.

\section{3. 測定項目}

1）胃炎の評価：胃粘膜に存在するペプシノーゲンには胃 体部にの及存在する PGI と, 胃全体にわたり存在する PGII の 2 つ分画がある. 胃粘膜に炎症が惹起される と胃粘膜内の PG は血中に放出され, 血中 PGI, PGII と もに上昇する，通常，この時の上昇率は PGII >PGI で あるために, PGI/II 比は低下寸る。 これらの変化は $H$. pylori 除菌治療により可逆的に変化することから，血 清ペプシノーゲン值 (PGI, PGII, PGI/II) は, 胃炎の程度 を反映する指標と考觉られている ${ }^{19}$ ，本研究では，血 清 PGI, PGII, PGI/II 測定を行い，胃炎の程度を評価し た.

2) H. pylori 菌量の評価 :

a) HpSA（便中 H. pylori 抗原）值：胃内性息する $H$. pylori の菌体は翼便中から排泄される. 本研究では, Hp 菌体成分を抗原とする HpSA 測定キットを用いて，便 中に排泄される $\mathrm{Hp}$ 菌量を評価した ${ }^{20)}$.

b) 尿素呼気試験 (urea breath test:UBT) 胃内 H. pylori 由来 のウレアーゼ活性を反映する尿素呼気試験を行い，胃 内に生存する viable H. plyori の量を評価した ${ }^{21)}$.

3）スルフォラファン吸収量の評価
消化管より体内に吸収されたスルフォラファンは肝内 で代謝され， dithiocabamates (DTC) に変換されて尿中に 排泄される22). 本研究では, 尿中 DTC 量を測定すること により，体内に吸収されたスルフォラファン量を評価し た.

以上の成績を $\mathrm{BS}$ 群と $\mathrm{AS}$ 群とで比較検討した.

\section{成 績}

1. HpSA 值 : BS 群でのみ拱食 8 週後に OD 值が有意に 低下した。摂食終了 2 个月後には OD 值は前値に復 した（図 7)

2. UBT 值: BS 群での久拱食 8 週後に UBT 值が有意に 低下した. 摂食終了 2 ヶ月後には UBT 值は前值に復 した.

3. ペプシノーゲン值: BS 群での久椇食開始後経時的に PGI, PGII 值の有意な低下, 及び PGI/II 比の上昇が認 められた。掑食終了 2 ヶ月後には前值に復した（図 7).

4. 尿中 DTC : スルフォラファンの体内吸収量を反映す る指標である尿中 DTC は，BS 投与群での久，摂食 中に有意な増加が認められた。

5. 胃炎の改善度とスルフォラファン吸収量の相関 : BS 群に沶いて, BS 摂取による胃炎の改善度を反映する $\mathrm{PGI} / \mathrm{II}$ の上昇幅と, スルフォラファンの体内吸収量 を反映する尿中 DTC の増大幅の間に, 有意に正の相 関が認められた。

以上より，スルフォラファン含有食品である BS を 8 週間継続的に摂取することにより，ヒトに打いて $H$.

\section{ブロッコリースプラウト摂食による H.pylori 菌量と胃炎の変化}
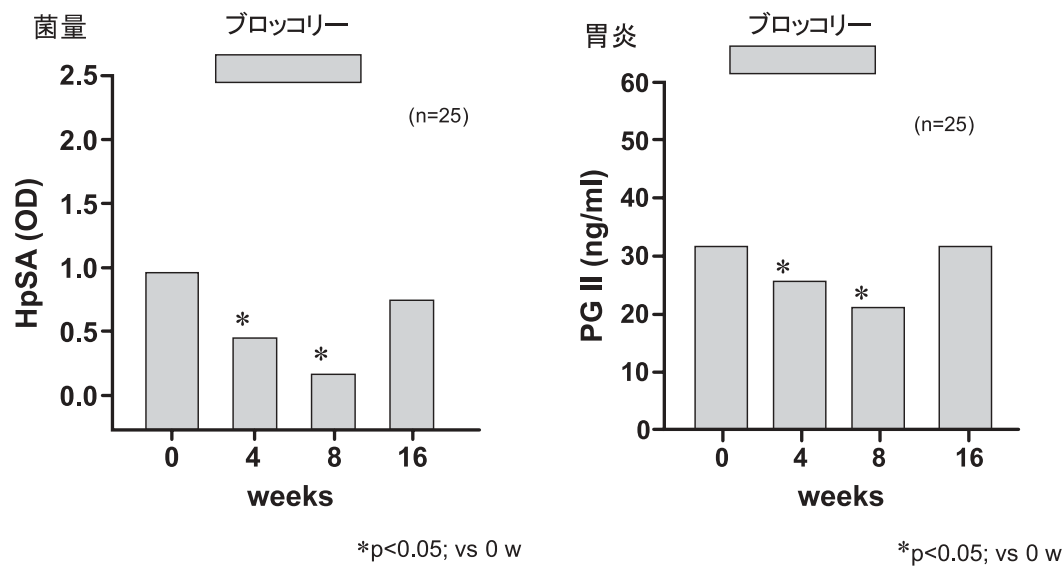

図 7 BS 投与がヒト便中 H. pylori 菌量 (HpSA), 及び胃炎の程度（PGII 值）に及ぼす影響 
pylori の菌量が減少し, 胃癌発症の母地である胃炎が改 善することが確認された。

\section{考 察}

本研究に抒いて H. pylori 感染マウスを用いた実験成績 は，以下の重要な点を明らかにした。第 1 に，in vivoの H. pylori 感染胃粘膜において, スルフォラファンを含む ブロッコリースプラウトの経ロ投与が胃炎軽減作用と胃 粘膜萎縮予防効果を有することが確認された. 今回用い たスルフォラファンの投与量 $(4.5 \mathrm{mg} / \mathrm{kg} /$ day $)$ は，ヒトに 換算すると，ブロッコリースプラウトとして約 $100 \mathrm{~g} / \mathrm{day}$ であり，通常の食事で摂取可能な量であることから，七 トに敃てもブロッコリースプラウト摂取による胃がん 予防の可能性が示唆された. 第 2 に, スルフォラファン の胃炎軽減作用が宿主側の転写因子 Nrf2 を介した胃粘 膜の酸化ストレス応答能強化に基づくものであることが 明らかにされた. H. pylori 感染胃粘膜は，白血球の著明 な浸潤により恒常性に酸化ストレスを受けているので, 酸化ストレス応答能活性化作用を有するスルフォラファ ンが H. pylori 感染胃粘膜に対して防御的に作用する可能 性が想定される．第 3 に，スルフォラファン投与による H. pylori 菌数の減少は nrf2 遺伝子欠損マウスでは認めら れなかったことから，スルフォラファンはin vivoのマウ スでは直接 H. pylori に作用する可能性よりも nrf2を介し て宿主胃粘膜の免疫機能を強化する結果, 2 次的に $H$. pylori 菌量を減少させる可能性が高いと考えられる.

本研究に打けるヒトでの臨床介入試験成績は，通常の 食生活の範囲内で摂取可能な量の BSを継続的に摂取す ることにより, H. pylori 胃炎を改善しらることを明らか にした点で極めて重要である.今回の検討では，ヒトに おいても BS 摂取後に H. pylori 菌量の低下が認められた が，その機序として，スルフォラファンの胃粘膜の免疫 能強化作用と, H. pylori に対する直接的な抗菌作用の 2 つの可能性が考えられる.

本研究は動物実験で得られた成績に基づいて，ヒトに おいて臨床介入試験を企画し，臨床への利益還元を目指 したトランスレーショナルリサーチであり, スルフォラ ファンの胃がん発症の予防効果をヒトに颃いて検証する ことが最終目標である. そのために今後は対象被験者を 胃癌発症のハイリスクグループにしぼりこみ, より長期 間の介入試験を実施したいと考えている.

\section{参 考 文 献}

1) Uemura N, Okamoto S, Yamamoto S, et al. Helicobacter pylori infection and the development of gastric cancer. $\mathrm{N}$ Engl J Med 2001; 345: 784-789.

2) Watanabe $T$, Tada $M$, Nagai $H$, et al. Helicobacter pylori infection induces gastric cancer in mongolian gerbils. Gastroenterology 1998; 115: 642-648.

3) Correa P. Human gastric carcinogenesis: a multistep and multifactorial process-First American Cancer Society Award Lecture on Cancer Epidemiology and Prevention. Cancer Res 1992; 52: 67356740 .

4) Wong BC, Lam SK, Wong WM, et al. China Gastric Cancer Study Group. Helicobacter pylori eradication to prevent gastric cancer in a high-risk region of China: a randomized controlled trial. JAMA 2004; 291: 187-194.

5) Take S, Mizuno M, Ishiki K, et al. The effect of eradicating Helicobacter pylori on the development of gastric cancer in patients with peptic ulcer disease. Am J Gastroenterol 2005; 100: 10371042.

6) Thomson CA, LeWinn K, Newton TR, et al. Nutrition and diet in the development of gastrointestinal cancer. Curr Oncol Rep 2003; 5: 192-202.

7) Cummings JH, Bingham SA. Diet and the prevention of cancer. BMJ 1998; 317(7173): 1636-1640.

8) Kelley JR, Duggan JM. Gastric cancer epidemiology and risk factors. J Clin Epidemiol 2003; 56: 1-9.

9) Tsugane S. Salt, salted food intake, and risk of gastric cancer: epidemiologic evidence. Cancer Sci 2005; 96: 1-6.

10) Fahey JW, Zhang Y, Talalay P. Broccoli sprouts: an exceptionally rich source of inducers of enzymes that protect against chemical carcinogens. P roc Natl Acad Sci U S A 1997; 94: 10367-10372.

11) Fahey JW, Talalay P. Antioxidant functions of sulforaphane: a potent inducer of Phase II detoxication enzymes.Food Chem Toxicol 1999; 37: 973-979.

12) Morimitsu Y, Nakagawa $Y$, Hayashi K, et al. A sulforaphane analogue that potently activates the Nrf2-dependent detoxification pathway. J Biol Chem 2002; 277: 3456-3463.

13) Fahey JW, Haristoy X, Dolan PM, et al. Sulforaphane inhibits extracellular, intracellular, and antibiotic-resistant strains of Helicobacter pylori and prevents benzo[a]pyrene-induced stomach tumors. Proc Natl Acad Sci U S A 2002; 99: 7610-7615.

14) Lee SA, Kang D, Shim KN, et al. Effect of diet and Helicobacter pylori infection to the risk of early gastric cancer. J Epidemiol 2003; 13: $162-168$.

15) Fox JG, Dangler CA, Taylor NS, et al. High-salt diet induces gastric epithelial hyperplasia and parietal cell loss, and enhances Helicobacter pylori colonization in C57BL/6 mice. Cancer Res 1999; 59: 4823-4828.

16) Yanaka $A$, Cho $S$, Tauchi $M$, et al. High salt diet accelerates progression of atrophy of Helicobacter pylori-infected gastric corpus mucosa in wild type C57/B6 mice, but not in IL-1 receptor knockout mice in vivo. Gastroenterology 2002; 122: A-1. 
17) Nozaki K, Shimizu N, Inada K, et al. Synergistic promoting effects of Helicobacter pylori infection and high-salt diet on gastric carcinogenesis in Mongolian gerbils. Jpn J Cancer Res 2002; 93: 1083-1089.

18) Ramos-Gomez M, Kwak MK, Dolan PM, et al. Sensitivity to carcinogenesis is increased and chemoprotective efficacy of enzyme inducers is lost in nrf2 transcription factor-deficient mice. Proc Natl Acad Sci U S A 2001; 98: 3410-3415.

19) Vaira D, Holton J, Menegatti M, et al. Blood tests in the management of Helicobacter pylori infection. Italian Helicobacter pylori Study Group. Gut 1998; 43 Suppl 1: S39-S46.
20) Gisbert JP, Pajares JM. Stool antigen test for the diagnosis of Helicobacter pylori infection: a systematic review. Helicobacter 2004; 9: 347-368.

21) Gisbert JP, Pajares JM. ${ }^{13} \mathrm{C}$-urea breath test in the management of Helicobacter pylori infection. Dig Liver Dis 2005; 37(12): 899906.

22) Ye L, Dinkova-Kostova AT, Wade KL, et al. Quantitative determination of dithiocarbamates in human plasma, serum, erythrocytes and urine: pharmacokinetics of broccoli sprout isothiocyanates in humans. Clin Chim Acta 2002; 316: 43-53.

\title{
ABSTRACT \\ Daily Intake of Sulforaphane-Rich Broccoli Sprouts Suppresses H. pylori Colonization and Attenuates $H$. pylori-induced Gastritis via Upregulation of Nrf2-dependent Antixodaint Enzymes
}

\author{
Akinori YANAKA ${ }^{1}$, Masafumi TAUCHI ${ }^{1}$, Masayuki YAMAMOTO ${ }^{2}$, Ichinosuke HYODO ${ }^{1}$ \\ ${ }^{1}$ Department of Gastroenterology, Graduate School of Comprehensive Human Sciences, University of Tsukuba \\ ${ }^{2}$ Tohoku University School of Medicine
}

Background: Sulforaphane (SFN), a compound abundant in broccoli sprouts (BS), protects cells from oxidative injury by activating nrf2-mediated antioxidant enzymes. Sulforaphane also shows bactericidal activity against H. pylori in vitro. The aim of this study was to determine if daily intake of SFN-rich BS inhibits H. pylori colonization and mitigated gastritis in H. pyloriinfected gastric mucosa in mice and humans.

Methods: Study 1: Nrf2+/+ and nrf2-/- C57BL/6 female mice were infected with H.pylori Sydney Strain; SS1. Mice were maintained for 2 mo. on a high salt diet $(7.5 \% \mathrm{NaCl})$, supplemented with or without BS containing approximately $2.5 \mathrm{mM} \mathrm{SFN}$. Degree of gastritis was evaluated by updated Sydney system. Study 2: Fifty subjects infected with H. pylori were randomly assigned to either the BS group ( $\mathrm{n}=25$ ) or the Alfalfa Sprouts (AS) group ( $\mathrm{n}=25$ ). All subjects were asked to eat BS $70 \mathrm{~g} /$ day (containing approximately $180 \mathrm{mg} \mathrm{SFN}$ ) or AS $70 \mathrm{~g} /$ day (no SFN) for 2 months. H.pylori colonization was evaluated by measurement of HpSA. The degree of gastritis was evaluated by measuring serum levels of pepsinogen (PG) I and II.

Results: Study 1: BS treatment decreased Hp colonization and mitigated gastritis in nrf2+/+ but not in nrf2-/- mice. Study 2: Two months intervention with BS decreased HpSA values and serum levels of PG I and II, while AS showed on effect.

Conclusion: Daily intake of SFN-rich BS suppresses H.pylori colonization and improves gastritis in H. pylori-infected gastric mucosa via nrf2-dependent mechanisms.

Key words: broccoli sprout, sulforaphane, Helicobacter pylori, gastritis, oxidative stress 